\title{
Controversies over Statins-related Cognitive Impairment
}

\author{
Shahu Ingole*, Rishi Jain, Tushar Tamboli \\ Medical Services, Emcure Pharmaceuticals Ltd., India
}

Copyright $\odot 2016$ by authors, all rights reserved. Authors agree that this article remains permanently open access under the terms of the Creative Commons Attribution License 4.0 International License

\begin{abstract}
The US FDA in 2012 released a safety announcement of risk of cognitive impairment with statin use. However, because this probable adverse event is conflicting with findings of several studies that demonstrate a potential benefit on cognition with the use of statins, we thought to do further analysis to clear the confusion. Reports of statin-associated cognitive impairment were found principally in few observational studies (e.g., case reports/series) and occasionally in few randomised trials. On the contrary, in the majority of observational studies and randomized controlled clinical trials, statins were found to have either a no effects or rather beneficial effect on cognition. However, should it happens, switching from lipophilic to hydrophilic statins such as Rosuvastatin may resolve this issue of cognitive impairment. Therefore, in spite of some concerns of cognitive impairment with statins, the current evidences do not favour the changing practice with respect to statin use, though one needs to be vigilant and address efficiently if it occurs at all.
\end{abstract}

Keywords Statin, Cognitive Impairment, Lipophilic Statins, Rosuvastatin

\section{Effects of Statins on Cognition: You'll Live Longer, But Will You Remember It?}

HMG coenzyme A reductase Inhibitors - 'Statins' have become the most commonly prescribed hypolidemic agents since their introduction in 1987 [1]. Currently, statins are a major contributor to cardiovascular disease prevention [2]. To reduce low-density lipoprotein cholesterol (LDL-C) and minimize the cardiovascular morbidity and mortality, statins are the most effective and predominantly used hypolidemic agents [3]. Apart from its hypolipidemic action, it has also been reported that statins reduce vascular inflammation and slow down the development of atherosclerosis by a mechanism independent of their lipid lowering effects, referred to as "pleiotropic effects[4]." Statins are well tolerated and have less adverse effects; myopathies, diarrhoea, changes in liver enzymes, and rhabdomyolysis have been reported [5]. However, some adverse effects do not become evident in clinical trials but become apparent after use in real world clinical practice and use in broader patient populations. On similar lines, several case reports and case series have suggested a budding link between statins and cognitive impairment [6-11]. Recently, Suraweera et al. reported cases of two Asian patients who developed cognitive deficits after initiation of simvastatin. A 32-year-old man and a 54-year-old woman developed different but clear cognitive deficits that reversed after stopping Simvastatin [12]. However, because this probable adverse event is conflicting with findings of several studies that demonstrate a potential benefit on cognition with the use of statins, it merits further analysis to clear the confusion [13-16].

This review is in fact prompted by the U.S. Food and Drug Administration (FDA) statement on cognitive impairment with statins, which came as a bolt from the blue to many physicians [17]. Many practitioners really wondered what the body of evidence was and what the rationale for that decision was. The suggested label revision may have important public health impact like restricting the use of statins or reducing the doses of statins in patients with established cardiovascular diseases and thereby depriving them the cardiovascular benefits. However, despite the warning on cognitive impairment by US FDA, the exact link between statins and cognition remains unidentified.

\section{The US FDA Warning}

The US FDA in 2012 released a safety announcement of risk of cognitive impairment. Explicitly, the US FDA highlighted that ill-defined memory loss and confusion were the major cognitive effects observed in statin users [17].

To further provide the rationale on the warning, the US FDA in its report says that for several years US FDA has analysed reports of cognitive impairment with statin. It has reviewed databases that reported cognitive impairment with statins and also some clinical trials that evaluated the effects of statins on cognition.

Certain observational studies $[10,11,18-23]$ and randomized controlled trials [24-26] have been cited by the 
US FDA for the cognitive impairment risk with statins and highlighted that these concerns were not related to progressive or fixed dementias such as Alzheimer disease.

This warning mainly affected almost all the statin like lovastatin, rosuvastatin, fluvastatin, atorvastatin, pitavastatin, pravastatin and Simvastatin [17]. However, what is more important here is that while releasing this warning, the US FDA has also emphasized that "The value of statins in preventing heart disease has been clearly established" and "Their benefit is indisputable, but they need to be taken with care and knowledge of their side effects."

\section{What Does the Data Suggest? Heart Saviour Coming at the Price of Brain?}

Statins by blocking HMG-CoA reductase enzyme are useful as lipid lowering therapeutics and have specifically been beneficial in patients with high cholesterol levels and as secondary prevention measures in patients suffering from cardiovascular events. Rosuvastatin particularly has cardiovascular benefits by increasing nitric oxide (NO) bioavailability and due to its sulfur content may potentially exhibit antioxidant effects [27]. It is one of the most effective statins available for reducing LDL-C and improving HDL-C, enabling more high-risk patients to achieve their lipid goals. Its favorable balance of effects on atherogenic and protective lipoproteins and its pleiotropic actions are associated with slowing of progression of atherosclerosis within the artery wall and with the clinical benefits of improved cardiovascular outcomes [28]. The JUPITER trial, largest study conducted to assess the beneficial effect of rosuvastatin therapy on the primary prevention of cardiovascular disease (CVD) demonstrated a highly significant $44 \%$ reduction in cardiovascular events [29].

However, occurrence of some cases of cognitive impairment have raised question on safety profile of statins inspite of its undisputed cardiovascular benefits. Reports of statin-associated cognitive impairment were found principally in few observational studies (e.g., case reports/series) and occasionally in few randomised trials. On the contrary, in the majority of observational studies and randomized controlled clinical trials, statins were found to have either a no effects or rather beneficial effect on cognition [30]. In a narrative overview of statin safety, it was concluded that there is no increased risk of cognitive impairment with statin and that the FDA label changes should not change clinical practice [31].
Various level 3 / level 4 evidences suggested that there was no increased incidence of Alzheimer disease and no impact on cognitive performance related to attention, procedural memory or motor speed with statin therapy. Similarly, level 2 evidences found that statin therapy did not result in to higher incidence of cognitive impairment or dementia Also, very few reports of cognitive impairment with statin were observed in FDA post-marketing surveillance databases, incidence of which was almost similar to that is usually observed with other cardiovascular drugs [32].

Various short-term trials suggest no consistent effect of statin therapy on cognitive end points. The most common short-term end point used was Digit Symbol Substitution Testing (a well-validated measure of cognitive function) and it was observed that there were no significant differences in the mean change in Digit Symbol Substitution Testing from baseline to follow-up between the statin and placebo groups (296 total exposures in 3 trials) [33]. Long-term cognition studies with mean exposure duration of 3 to 24.9 years enrolled 23,443 patients. No association was found between statin use and incident dementia in 3 studies and on the contrary, 5 studies found a favourable effect. Overall, there was $29 \%$ reduction in incident dementia in statin-treated patients in a pooled analysis (hazard ratio, $0.71 ; 95 \% \mathrm{CI}$, 0.61-0.82) [27].

On the other hand, statins for the prevention and treatment of dementia first created attention in 2000 when it was observed in 2 epidemiologic studies that statin use is associated with lower risk of dementia. Two more recently published meta-analyses found a potential benefits on cognition. However, further research post this observation reported mixed results [33].

\subsection{Observational Studies and Cognition}

Most of the studies have demonstrated either a beneficial effect or no effect of statins on cognitive function and the risk of dementia. However, in a review by Bitzur, few observational studies (Table 1) were analyzed for association between statin use and cognitive decline [2]. Out of the studies below, a study involving 57,669 individuals aged 65 years with no history of dementia from Taiwan showed that a higher exposure to statins was associated with decreased risk of dementia, and the use of potent statins was (atorvastatin, rosuvastatin) was associated with a lower risk of dementia than the use of less potent statins. Another study, showed an association between statin use and increased risk of cognitive decline as an acute effect, which was also seen with other non statin lipid lowering drugs. 
Table 1. Observational studies of cognitive effect of statins [2]

\begin{tabular}{|c|c|c|c|c|c|}
\hline Design & $\begin{array}{l}\text { No. of } \\
\text { subjects }\end{array}$ & Age (years) & $\begin{array}{l}\text { Follow-up } \\
\text { (years) }\end{array}$ & Diagnosis of dementia & Results $(95 \% \mathrm{CI})$ \\
\hline Nested case control & 1364 & $50-89$ & N/A & $\begin{array}{c}\text { Computer-recorded clinical } \\
\text { diagnosis }\end{array}$ & RR $0.29(0.13-0.63)$ \\
\hline Case control & 655 & Mean 78.7 & N/A & Clinical diagnosis and MMSE & OR $0.23(0.1-0.56)$ \\
\hline Case control & 2305 & $\geq 65$ (average 70.3 ) & $\mathrm{N} / \mathrm{A}$ & Clinical diagnosis and MMSE & OR $0.26(0.08-0.88)$ \\
\hline $\begin{array}{l}\text { Prospective } \\
\text { observational }\end{array}$ & 1037 & Mean 70 & 4 & MMSE & OR $0.67(0.42-1.05)$ \\
\hline $\begin{array}{l}\text { Retrospective } \\
\text { cohort }\end{array}$ & 1290071 & $\geq 65$ (average 74.6) & N/A & ICD-9 & HR $0.46(0.44-0.48)$ \\
\hline $\begin{array}{l}\text { Prospective } \\
\text { observational }\end{array}$ & 1674 & $\geq 60($ Mean 70$)$ & 5 & DSM-IV & HR $0.52(0.34-0.80)$ \\
\hline $\begin{array}{l}\text { Prospective } \\
\text { observational }\end{array}$ & 6992 & Mean 69.4 & Mean 9 & DSM-III-R & HR $0.57(0.37-0.90)$ \\
\hline $\begin{array}{l}\text { Propensity } \\
\text { analysis }\end{array}$ & 57669 & $\geq 65$ (average 72.9 ) & $\begin{array}{c}\text { Median } \\
11.8\end{array}$ & ICD-9 & $\begin{array}{l}\text { HR } 0.385-0.829 \text { depending on } \\
\text { exposure }\end{array}$ \\
\hline $\begin{array}{l}\text { Prospective } \\
\text { cohort }\end{array}$ & 478 & 80 & 69 & MHT & $\begin{array}{c}\mathrm{F}=5.78 \text { for IQ change from } \\
\text { childhood }\end{array}$ \\
\hline $\begin{array}{l}\text { Retrospective } \\
\text { cohort }\end{array}$ & 13626 & $30-85($ mean 61$)$ & 7 & ICD-9 & $\begin{array}{c}\text { OR } 1.56(1.19-2.03) \text { in } \\
\text { nonpersistent vs. } \\
\text { persistent statin user }\end{array}$ \\
\hline Cross-sectional & 24595 & $\geq 45$ & N/A & SIS & OR $1.03(0.86-1.24)$ \\
\hline Case control & 548 & $\geq 65 \quad($ median 72$)$ & N/A & Various tests & $\begin{array}{c}\text { OR } 0.8-1.5 \text { depending on test, } \mathrm{P}= \\
\text { NS }\end{array}$ \\
\hline $\begin{array}{l}\text { Retrospective } \\
\text { cohort }\end{array}$ & 2798 & $\geq 65(56.7 \%>80)$ & $\mathrm{N} / \mathrm{A}$ & Various tests & HR $0.57(0.77-1.52)$ \\
\hline $\begin{array}{l}\text { Prospective } \\
\text { observational }\end{array}$ & 3587 & Mean 72.8 & 3.4 & CDR-SOB, MMSE & $\mathrm{P}=\mathrm{NS}$ for deterioration \\
\hline $\begin{array}{l}\text { Observational } \\
\text { cohort }\end{array}$ & 756 & Mean 74.2 & $\mathrm{~N} / \mathrm{A}$ & Trail Making Test Part & $\mathrm{P}=\mathrm{NS}$ \\
\hline $\begin{array}{l}\text { Retrospective } \\
\text { cohort }\end{array}$ & 991570 & Mean 63.8 & 30 days & $\begin{array}{c}\text { Computer-recorded clinical } \\
\text { diagnosis }\end{array}$ & OR $4.40(3.01-6.41)$ \\
\hline
\end{tabular}

CDR-SOB, Clinical Dementia Rating Sum of Boxes; IQ, intelligence quotient; MHT, Moray House Test; N/A, not applicable; NS, nonsignificant; RR, relative risk; SIS, Six-Item Screener.

\subsection{Randomized Controlled Trials and Cognition}

Two large randomized trials (PROSPER) and Heart Protection study have studied the effects of pravastatin and simvastatin respectively in comparison with placebo on cognitive function $[34,35]$. Both the studies showed cognitive impairment with statins, however, there was no significant difference when both the treatments were compared with placebo. 
Table 2. Randomized controlled trials with the relationship between statin use and cognitive function as a primary outcome [2]

\begin{tabular}{|c|c|c|c|c|c|}
\hline $\begin{array}{l}\text { No. of } \\
\text { subjects }\end{array}$ & $\begin{array}{l}\text { Age } \\
\text { (years) }\end{array}$ & Follow-up & Diagnosis of cognitive function & $\begin{array}{l}\text { Statin tested } \\
(\mathrm{mg})\end{array}$ & Results $(95 \% \mathrm{CI})$ \\
\hline 25 & $\begin{array}{c}\text { Average } \\
23.8\end{array}$ & 4 weeks & Digit symbol substitution test & $\begin{array}{c}\text { Simvastatin } 40, \\
\text { pravastatin } 40\end{array}$ & $\mathrm{P}=\mathrm{NS}$ \\
\hline 22 & $36-65$ & 6 weeks & $\begin{array}{c}\text { Rey Auditory Learning, Trail Making Test, } \\
\text { Embedded Figures, Benton Visual Retention, } \\
\text { Verbal fluency }\end{array}$ & $\begin{array}{l}\text { Lovastatin } 40, \\
\text { pravastatin } 40\end{array}$ & $\mathrm{P}=\mathrm{NS}$ \\
\hline 36 & Mean 51 & 4 weeks & $\begin{array}{l}\text { Digit symbol substitution, auditory vigilance, } \\
\text { selective reminding word recall, choice reaction } \\
\text { time, finger tapping }\end{array}$ & $\begin{array}{l}\text { Simvastatin } 20 \\
\text { pravastatin } 40\end{array}$ & $\mathrm{P}=\mathrm{NS}$ \\
\hline 36 & Mean 50 & 4 weeks & $\begin{array}{l}\text { Digit symbol substitution, choice reaction time, } \\
\text { auditory vigilance, selective reminding word } \\
\text { recall, finger tapping }\end{array}$ & $\begin{array}{l}\text { Lovastatin } 40, \\
\text { pravastatin } 40\end{array}$ & $\mathrm{P}=\mathrm{NS}$ \\
\hline 367 & Mean 71 & 6 months & Digit symbol substitution & $\begin{array}{l}\text { Lovastatin } 20- \\
\quad 40\end{array}$ & $\mathrm{P}=\mathrm{NS}$ \\
\hline 308 & Mean 54 & 6 months & 12 neuropsychological tests & $\begin{array}{l}\text { Simvastatin } \\
10-40\end{array}$ & $\begin{array}{c}\text { Detrimental effect on recurrent } \\
\text { words, Elithorn maze, and 4-word } \\
\text { short-term memory tests. }\end{array}$ \\
\hline 209 & Mean 46 & 6 months & 10 neuropsychological tests & $\begin{array}{l}\text { Lovastatin } 20- \\
\qquad 40\end{array}$ & $\begin{array}{l}\text { Detrimental effect on attention } \\
\text { and psychomotor speed domains, } \\
\text { as well as digit vigilance, } \\
\text { recurrent words, Elithorn maze, } \\
\text { and grooved pegboard tests }\end{array}$ \\
\hline 82 & Mean 34 & 4 weeks & 10 neuropsychological tests & $\begin{array}{l}\text { Lovastatin } 40 \\
\text { pravastatin } 40\end{array}$ & $P=N S$ \\
\hline 1016 & $>20$ & 6 months & $\begin{array}{l}\text { Recurrent words, Elithorn maze, digit vigilance, } \\
\text { grooved pegboard tests }\end{array}$ & $\begin{array}{l}\text { Simvastatin } 20 \\
\text { pravastatin } 40\end{array}$ & $\mathrm{P}=\mathrm{NS}$ \\
\hline 97 & Mean 57 & 6 months & 8 neuropsychological tests & Atorvastatin 10 & Beneficial effect on all domains \\
\hline 57 & Mean 62 & 73 weeks & $\begin{array}{c}\text { Digit Symbol Coding subtest, Trail Making Test, } \\
\text { Stroop Color-Word Reading Test }\end{array}$ & Atorvastatin 10 & $\mathrm{P}=\mathrm{NS}$ \\
\hline 30 & $45-75$ & 30 weeks & 8 neuropsychological tests & $\begin{array}{c}\text { Atorvastatin } \\
10-80\end{array}$ & $\begin{array}{l}\text { Beneficial effect on verbal } \\
\text { memory }\end{array}$ \\
\hline
\end{tabular}

NS, nonsignificant

\section{Recognition of Cognitive Impairment}

As highlighted by the US FDA statement, the reports about memory loss, forgetfulness and confusion span all statins and all age groups. Generally, the symptoms were not serious and were reversible within a few weeks after the patient stopped using the statin. Few patients reported feeling "fuzzy" or unfocused thinking [17].

Largely, cognition may be subdivided under 4 domains e.g. memory, executive function, language and visuospatial ability. Cognitive impairment can therefore be defined as a decline in any of these 4 domains from baseline and sometimes may be overlapping one another [36].

Table 3. Cognition Tests [36]

\begin{tabular}{|c|c|c|c|c|}
\hline & MMSE & 3MS Test & ADAS-Cog & DSST \\
\hline Goal & \multicolumn{3}{|c|}{$\begin{array}{l}\text { To evaluate orientation (time, place), registration, attention and calculation, recall, } \\
\text { language, ability to follow commands }\end{array}$} & $\begin{array}{l}\text { To evaluate attention, short-term } \\
\text { memory, processing speed }\end{array}$ \\
\hline Description & $\begin{array}{l}11 \text { questions } \\
(10 \text {-min test })\end{array}$ & $\begin{array}{l}24 \text { questions (15-min test) As the } \\
\text { MMSE but more comprehensive with } \\
\text { different levels of difficulties }\end{array}$ & $\begin{array}{l}11 \text { blocks of different } \\
\text { tasks to do (30- to } 45 \text {-min } \\
\text { test). More in-depth test }\end{array}$ & $\begin{array}{l}\text { Consists of } 9 \text { digits and symbols to pair. } \\
\text { Under each digit, the subject writes down } \\
\text { the corresponding symbol, pairing as } \\
\text { many as possible in } 90 \mathrm{~s} \text {. }\end{array}$ \\
\hline Score range & $0-30$ & $0-100$ & $0-70$ & $\begin{array}{c}0-76^{*} \text { (number of correct pairs of } \\
\text { symbols/digits) }\end{array}$ \\
\hline $\begin{array}{l}\text { Threshold } \\
\text { for } \\
\text { diagnosis }\end{array}$ & $\begin{array}{l}\geq 26: \text { no or } \\
\text { questionable } \\
\text { impairment } \\
\text { 21-25: mild } \\
\text { 11-20: moderate } \\
0-10: \text { severe }\end{array}$ & $\begin{array}{l}<79 \text { suggests cognitive impairment } \\
<48 \text { suggests severe impairment }\end{array}$ & $\begin{array}{l}\text { Score } \geq 18 \text { suggests } \\
\text { greater cognitive } \\
\text { impairment. } \\
\text { A 4-point change in } 6 \\
\text { months is a clinically } \\
\text { significant difference. }\end{array}$ & $\begin{array}{l}\text { A low score indicates cognitive } \\
\text { impairment but no specific threshold } \\
\text { defined. }\end{array}$ \\
\hline
\end{tabular}

ADAS-Cog: Alzheimer's Disease Assessment Scale-Cognition; DSST: Digital Symbol Substitution Test; MMSE: Mini Mental State Examination; 3MS Test: Modified Mini-Mental State Test.

*In theory, the maximum score is 90 ; in practice, the maximum is set at 76 . 


\section{Managing Cognitive Impairment as a Side Effect Should It Happens}

Although most of the available data suggest no impairment in cognition with use of statins, based on expert opinion, a series of steps has been recommended by the Statin Cognitive Safety Task Force (SCSTF) should a patient report cognitive impairment after initiation of therapy. It recommends finding out other potential contributors such as anticholinergic medications (e.g. tricyclic antidepressants and certain antipsychotics), cognitive testing and performing a benefit-risk assessment of stopping or decreasing the dose versus continuing the statin. Statins have strong evidence to support their use in secondary prevention of cardiovascular events. Therefore, it becomes vital to discuss with the patients the risks of stopping statin therapy which may result in to increased risk of cardiovascular events or continuing statin therapy with some risk of cognitive impairment. If it is suspected that the statin is contributing to the cognitive impairment, a trial of drug-free period of 1 to 2 months prior to a rechallenge can be recommended. Also, expert opinion suggests a switch to a less lipophilic statin such as Rosuvastatin or Pravastatin to diminish the effects on cognition [36]. Preliminary data suggest that less lipophilic statins e.g. pravastatin and rosuvastatin may be less likely to be associated with the risk of cognitive impairment because of poor penetration across the blood-brain barrier. In patients with suspected cognitive impairment due to another statin, the drugs like rosuvastatin would be a reasonable alternative [30].

\section{Conclusions}

Overall, the available literature suggests the rare occurrence of cognitive impairment with the use of statins as evidenced by occasional reports of statin-associated cognitive impairment. The short-term data do not support the association of cognitive impairment and statins in patients without baseline cognitive dysfunction. On the other hand, the long-term data may support a favourable role of statins in the prevention of dementia. However, to draw unequivocal conclusions about the either effects of statins on cognition, well-designed, randomised controlled studies in large number of patients are needed. If cognitive impairment is suspected in any patient on statin therapy, it is essential to look at other causes before attributing it to statin. Should it happens, switching from lipophilic to hydrophilic statins such as Rosuvastatin may resolve this issue of cognitive impairment. Also, in case of suspected ADR, it is imperative to always highlight the well-recognised cardiovascular benefits of statins, including stroke reduction before discontinuation of treatment. Probably, there is no need to press the panic button on concerns of cognitive impairment with statin therapy as the majority of evidences suggest cardiovascular benefits of statins and possible cognitive benefits prevail over the risk of cognitive impairment. Thus, in spite of some concerns of cognitive impairment with statins, the current evidences do not favour the changing practice with respect to statin use, though one needs to be vigilant and address efficiently if it occurs at all.

\section{REFERENCES}

[1] Wang TJ, Stafford RS, Ausiello JC. Randomized clinical trials and recent patterns in the use of statins, Am Heart J, Vol. 141, 957-63, 2001.

[2] Bitzur R. Remembering Statins: Do Statins Have Adverse Cognitive Effects? Diabetes Care 2016; 39(2): S253-S259.

[3] Genest J, McPherson R, Frohlich J. Canadian Cardiovascular Society/Canadian guidelines for the diagnosis and treatment of dyslipidemia and prevention of cardiovascular disease in the adult-2009 recommendations, Can J Cardiol, Vol. 25, 567-79, 2009.

[4] Mahmood D, Jahan K, Habibullah K. Primary prevention with statins in cardiovascular diseases: A Saudi Arabian perspective. J Saudi Heart Assoc 2015; 27:179-191

[5] Armitage J. The safety of statins in clinical practice, Lancet, Vol. 370, 1781-90, 2007.

[6] Peters JT, Garwood CL, Lepczyk M. Behavioral changes with paranoia in an elderly woman taking atorvastatin. Am J Geriatr Pharmacother, Vol. 6, 28-32, 2008.

[7] Galatti L, Polimeni G, Salvo F. Short-term memory loss associated with Rosuvastatin, Pharmacotherapy, Vol. 26, 1190-2, 2006.

[8] Padala KP, Padala PR, Potter JF. Simvastatin-induced decline in cognition, Ann Pharmacother, Vol. 40, 1880-3, 2006.

[9] King DS, Wilburn AJ, Wofford MR. Cognitive impairment associated with atorvastatin and Simvastatin, Pharmacotherapy, Vol. 23, 1663-7, 2003.

[10] Orsi A, Sherman O, Woldeselassie Z. Simvastatin-associated memory loss, Pharmacotherapy, Vol. 21, 767-9, 2001.

[11] Wagstaff LR, Mitton MW, Arvik BML. Statin-associated memory loss: analysis of 60 case reports and review of the literature, Pharmacotherapy, Vol. 23, 871-80, 2003.

[12] Suraweera C, de Silva V, Hanwella R. Simvastatin-induced cognitive dysfunction: two case reports, J MedCase Rep, Vol. $10,83,2016$.

[13] Kurata T, Miyazaki K, Kozuki M. Atorvastatin and pitavastatin improve cognitive function and reduce senile plaque and phosphorylated tau in aged APP mice, Brain Res, Vol. 1371, 161-70, 2011.

[14] Wolozin B, Kellman W, Rousseau P. Decreased prevalence of Alzheimer's disease associated with 3-hydroxy-3-methylglut aryl coenzyme A reductase inhibitors, Arch Neurol, Vol. 57, 1439-43, 2000.

[15] Jick H, Zornberg GL, Jick SS. Statins and the risk of dementia, 
Lancet, Vol. 356, 1627-31, 2000.

[16] Rockwood K, Kirkland S, Hogan DB. Use of lipid-lowering agents, indication bias, and the risk of dementia in community-dwelling elderly people, Arch Neurol Vol. 59, 223-7, 2002.

[17] http://www.fda.gov/downloads/ForConsumers/ConsumerUpd ates/UCM293705.pdf

[18] Zamrini E, McGwin G, Roseman JM. Association between statin use and Alzheimer's disease, Neuroepidemiology, Vol. 23, No. 1-2, 94-98, 2002.

[19] Zandi PP, Sparks DL, Khachaturian AS. Do statins reduce risk of incident dementia and Alzheimer disease? Arch Gen Psychiatry, Vol. 62, 217-224, 2005.

[20] Bettermann K, Arnold AM, Williamson J. Statins, risk of dementia, and cognitive function: secondary analysis of the Ginkgo Evaluation of Memory study, J Stroke Cerebrovascular Dis, Vol. 21, No. 6, 436-444, 2012.

[21] Beydoun M, Beason-Held LL, Kitner-Triolo MH. Statins and serum cholesterol's associations with incident dementia and mild cognitive impairment, J Epidemiol Community Health, Vol. 65, No. 11, 949-957, 2011.

[22] Evans M, Golomb B. Statin-associated adverse cognitive effects: survey results from 171 patients, Pharmacotherapy, Vol. 29, No. 7, 800-811, 2009.

[23] Parker BA, Polk DM, Rabdiya V. Changes in memory function and neuronal activation associated with atorvastatin therapy, Pharmacotherapy, Vol. 30, No. 6, 236e-240e, 2010.

[24] Muldoon MF, Barger SD, Ryan CM. Effects of lovastatin on cognitive function and psychological well-being, Am J Med, Vol. 108, No. 7, 538-546, 2000.

[25] Muldoon MF, Ryan CM, Sereika SM. Randomized trial of the effects of simvastatin on cognitive functioning in hypercholesterolemic adults, Am J Med, Vol. 117, No. 11, 823-829, 2004.

[26] Trompet S, Vliet P, Craen AJM. Pravastatin and cognitive function in the elderly: results of the PROSPER study, J Neurol, Vol. 257, No. 1, 85-90, 2010.

[27] Kumar AH. Hoping rosuvastatin for primary prevention of cardiovascular events, are all statins similar and are we ready for statinizing the globe?. J Nat Sc Biol Med 2016; 7:117-8

[28] $\mathrm{Hu} \mathrm{M}$, Tomlinson B. Current perspectives on rosuvastatin. Integrated Blood Pressure Control 2013; 6: 15-25

[29] Ridker PM, Danielson E, Fonseca FA, et al. Rosuvastatin to prevent vascular events in men and women with elevated C-reactive protein. N Engl J Med. 2008; 359:2195-2207

[30] Carlos H, Jean-Christy F. Is Statin-associated Cognitive Impairment Clinically Relevant? A Narrative Review and Clinical Recommendations, the Annals of Pharmacotherapy, Vol. 46, No. 4, 549-557, 2012.

[31] Jukema JW, Cannon CP, De Craen AJM. The controversies of statin therapy: weighing the evidence, J Am Coll Cardiol, Vol.60, No.10, 875-881, 2012.

[32] Karl Richardson, Marisa Schoen, Benjamin French. Statins and Cognitive Function: A Systematic Review, Ann Intern Med, Vol. 159, No. 10, 688-697, 2013.

[33] Swiger KJ, Manalac RJ, Blumenthal RS. Statins and cognition: a systematic review and meta-analysis of short- and long-term cognitive effects. Mayo Clin Proc, Vol. 88, No. 11, 1213-21, 2013.

[34] Trompet S, van Vliet $\mathrm{P}$, de Craen AJ, et al. Pravastatin and cognitive function in the elderly. Results of the PROSPER study. J Neurol 2010; 257:85-90

[35] Collins R, Armitage J, Parish S, Sleight P, Peto R; Heart Protection Study Collaborative Group. Effects of cholesterol-lowering with simvastatin on stroke and other major vascular events in 20536 people with cerebrovascular disease or other high risk conditions. Lancet 2004; 363:757767

[36] Jérémie MG, Anne Massicotte. Statins and their effect on cognition: Let's clear up the confusion, Can Pharm J (Ott), Vol. 148, No. 3, 150-155, 2015. 